\title{
ORGANIC WASTE'S POTENTIAL AS RENEWABLE ENERGY AT SUPIT URANG LANDFILL IN MALANG CITY
}

\author{
Riza Saadiah ${ }^{1}$, Hermawan $^{2}$, dan Hadiyanto ${ }^{3}$ \\ ${ }^{1}$ Magister of Environmental Science Diponegoro University, \\ Jl. Imam Bardjo, SH No.5 Semarang \\ ${ }^{2}$ Electrical Engineering Diponegoro University, Jl. Prof. H. Sudarto, SH Semarang \\ ${ }^{3}$ Chemical Engineering Diponegoro University, Jl. Prof. H. Sudarto, SH Semarang \\ Email: rizasaadiah@gmail.com
}

\begin{abstract}
This research are to know the correlation of the number of population with the amount of waste in Malang city and biogas potential at Supit Urang landfill. Then also counting the percentage of biogas which has been used as gas fuel by citizens around the landfill and as electrical energy potency. The average amount of waste in Malang city is 410,45 ton per day. Organic waste composition at Supit Urang landfill is $64,9 \%$ or in the average it's about $137.989,57 \mathrm{~kg}$ per day. From that amount, the average of biogas which is produced is $19.146,57 \mathrm{~m}^{3}$ per day or about $574.397,05 \mathrm{~m}^{3}$ per month. Biogas utilization is for fuel gas by 408 houses near the location of that landfill, that's about 18.385,19 $\mathrm{m}^{3}$ per month or about $3,2 \%$. Therefore that's still has $96,8 \%$ biogas potential or about $556.011,86 \mathrm{~m}^{3}$ per month which has not been utilized yet. That potency can produce electrical energy 2.613.255,75 $k W h$ per month or 3,63 MW. If the average efficiency level of conversion from biogas to electricity is $35 \%$, the electric potential become $914.639,51 \mathrm{kWh}$ per month or as big as power station with energy $1,27 M W$
\end{abstract}

Keywords: waste, global warming, greenhouse gas emission, biogas, renewable energy.

\section{INTRODUCTION}

Population growth will cause an increase in the amount of waste. If not anticipated with the right waste management, it will cause various problems. As the heaping of waste at landfill can cause environmental problems, that are vegetation damage, water pollution by leachate, air pollution by unpleasant odors, risk of asphyxiaton risk of explosion and combustion, and greenhouse gas emisisions (Popov, 2005 in Abreu, et al, 2011). Greenhouse gas emissions like carbondioxide gas $\left(\mathrm{CO}_{2}\right)$ and methane gas $\left(\mathrm{CH}_{4}\right)$ emit to the atmosfer so can cause ozon layer getting thinner and thinner. Accordingly there will be an increase in the earth temperature known as global warming.

The main contributor to the greenhouse effect is methane emission from landfill (Scharff and Jacobs, 2006). Methane gas emission 21 times more dangerous than $\mathrm{CO}_{2}$ emission (Czepiel, et al., 2003). Popov (2005) in Abreu, et al (2011) explained that $\mathrm{CH}_{4}$ and $\mathrm{CO}_{2}$ can be generated within 20 years, but their emissions can continue for 50 years or more.

Kyoto Protocol and Waste To Energy Program support each country and government to reduce greenhouse gas emission and utilize the waste as energy source. Therefore, waste management at landfill need to be done, one of that by using the biogas which are produced as renewable energy. This purpose is to prevent greenhouse gas emission and global warming and also reduce the using of source energy from fossil like petroleum and coal.

Global warming as environmental problem has happened at all part of the world. Greenhouse gas emission has a risk of causing global warming not only from waste heap, but also as the side effect from using fossil energy. The reserve of the source of fossil energy getting decrease, but renewable energy still have great potency as be seen at Table 1 . 
Jurnal Presipitasi

Vol. 12 No. 2 September 2015, ISSN 1907-187X

Table 1. Primer Energy Source in Indonesia (2005)

\begin{tabular}{|c|c|c|c|c|}
\hline \multicolumn{5}{|c|}{ Fossil Energy } \\
\hline Energy type & Resource & Reserve & $\begin{array}{l}\text { Product ion } \\
\text { (per year) }\end{array}$ & $\begin{array}{l}\text { Ratio Reserve/ Prod } \\
\text { (without exploration) year }\end{array}$ \\
\hline Petroleum & 86,9 billion barel & 9,1 billion barel & 387 million barel & 23 \\
\hline Gas & 384,7 TSCF & $\begin{array}{l}\text { 185,8 TSCF } \\
(\mathrm{P} 1+\mathrm{P} 2)\end{array}$ & 2,97 TSCF & 62 \\
\hline Coal & 58 billion ton & 19,3 billion ton & 132 million ton & 146 \\
\hline \multicolumn{5}{|c|}{ Renewable Energy } \\
\hline \multicolumn{2}{|c|}{ Non Fossil Energy } & \multicolumn{2}{|c|}{ Potency } & Rigged Capacity \\
\hline \multicolumn{2}{|l|}{ Water Energy } & \multicolumn{2}{|c|}{$75,67 \mathrm{GW}$} & $4,2 \mathrm{GW}$ \\
\hline \multicolumn{2}{|l|}{ Heat Energy } & \multicolumn{2}{|c|}{$27,14 \mathrm{GW}$} & $0,852 \mathrm{GW}$ \\
\hline \multicolumn{2}{|l|}{ Micro hydro } & \multicolumn{2}{|c|}{$0,46 \mathrm{GW}$} & $0,084 \mathrm{GW}$ \\
\hline \multicolumn{2}{|l|}{ Biomass } & \multicolumn{2}{|c|}{$49,81 \mathrm{GW}$} & $0,302 \mathrm{GW}$ \\
\hline \multicolumn{2}{|c|}{ Sun shines Energy } & \multicolumn{2}{|c|}{$4,80 \mathrm{kWh} / \mathrm{m}^{2} /$ day } & $0,008 \mathrm{GW}$ \\
\hline \multicolumn{2}{|l|}{ Wind Energy } & \multicolumn{2}{|c|}{$9,29 \mathrm{GW}$} & $0,0005 \mathrm{GW}$ \\
\hline
\end{tabular}

Source: Ministry Of Energy and Man Resource (2005) in Ministry Of Research and Technology (2006)

Efforts on energy conversion need to be done by encouraging green energy as renewable energy from organic waste biomass. It aims at getting energy sustainability. Government is expected to have a program for conversion from petroleum fuel to gas fuel and from waste to energy to reach sustainable development.

In the year of 2013 and 2014, Malang City government get appreciation of Adipura Kencana because of the success on waste management programs like Malang Waste Bank and biogas utilization at Supit Urang landfill. Biogas from the landfill has been utilized by the citizens around the landfill location as energy source, that is, as gas fuel.

The purpose of this research are not only to know the correlation of the number of population with the amount of waste in Malang City and biogas potential at Supit Urang landfill, but also to count the percentage of biogas which has been used as gas fuel by citizens around the landfill and as electrical energy potency.

\section{Biogas's Forming Process}

Biogas is generated from anaerobic waste decomposition process. Chemical reaction on that process is:

$$
\mathrm{C}_{6} \mathrm{H}_{12} \mathrm{O}_{6} \rightarrow 3 \mathrm{CH}_{4}+3 \mathrm{CO}_{2}
$$

According to Popov (2005) in Abreu, dkk (2011), anaerobic process happened for $10-50$ days.
Sudrajat (2006) explained that the anaerobic composting process on organic waste go through four steps, which are:

a. Hydrolysis process

In this process, there is a decomposition of polymer organic material to monomer which can easily leach and results in amino acid, volatile acid, glycerol, etc. Fat is described by lipolytic bacteria with lipase's enzyme, while carbohydrate is described by cellulotytic bacteria with cellulose enzyme, and protein is described by proteolytic bacteria with protease's enzyme.

b. Acydogenesis process

In this process, there is organic monomer decomposition becoming organic acids (as format acid, acetic, butirat, propionat, valeriat) and alcohol by acidogenic bacteria. Other results from that process are $\mathrm{CO}_{2}, \mathrm{H}_{2}$, and methanol.

c. Acetogenesis process

In this process, organic acid and alcohol is changed as acetate, format, methanol, $\mathrm{CO}_{2}$ and $\mathrm{H}_{2}$ by acetogenic bacteria

d. Metanogenesis process

In this process, acetate is changed as $\mathrm{CH}_{4}$, $\mathrm{CO}_{2}$, and $\mathrm{H}_{2} \mathrm{O}$ by metanogenic bacteria. Nearly about $70 \%$ methane are formed from acetates, whereas the other $30 \%$ are from format acid, $\mathrm{CO}_{2}$, and $\mathrm{H}_{2}$.

Biogas at landfill consist of $55-65 \% \mathrm{CH}_{4}, 35$ $45 \% \mathrm{CO}_{2}, 0-1 \% \mathrm{~N}_{2}, 0-1 \% \mathrm{H}_{2}$, and $0-1 \% \mathrm{H}_{2} \mathrm{~S}$ (Polpraset, 1996 in Abreu, et al, 2011). Methane 
is the main component from biogas. On hall temperature and standard pressure, this gas is colourless and does not have bad smell. This gas is inflammable.

According to Sudrajat (2006), the composition and calor of biogas are:

$$
\begin{array}{ll}
\mathrm{CH}_{4} & : 50-85 \% \\
\mathrm{CO}_{2} & : 15-50 \% \\
\mathrm{H}_{2} \mathrm{~S} & :<1 \% \\
\text { Calor value } & : 20-25 \mathrm{MJ} / \mathrm{m}^{3} \\
& \left(47.0-8.000 \mathrm{kkal} / \mathrm{m}^{3}\right)
\end{array}
$$

\section{Biogas Potential Counting}

The method to calculate energy for anaerobic digestion from organic waste are (Frear, et al in Sulistyo, 2010):

$$
\begin{aligned}
\text { TS } & =27,7 \% \times \mathrm{Q} \\
\text { VS } & =74,1 \% \times \mathrm{TS} \\
\text { VBS } & =0,676 \times \text { VS }
\end{aligned}
$$

where:

$Q$ is waste amount ( $\mathrm{kg} /$ day)

TS is total solid ( $\mathrm{kg} /$ day)

$V S$ is volatile solid ( $\mathrm{kg} /$ day)

VBS is biogas production volume $\left(\mathrm{m}^{3} /\right.$ day)

Lil, et al (2010); Yu, et al (2010); Schnurer and Jarvis (2010); Tatlidil, et al (2009); and Rao, et al (2000) in Ngumah (2013) stated that coefficient are used to estimate Biochemical Methane Potential (BMP) of biogas from organic waste of Municipal Solid Waste (MSW) is $66 \%$.

Biogas which will be utilized as electrical energy must be treated to increase its quality and consequent energy efficiency. The stability of efficiency level can be reached by adding blower so that biogas flow can give an adequate energy (Pierpaoli and Diotallevi, 2007). Conversion of biogas to electrical energy has efficiency level 30-40\% (Eurelectric, 2003).

Table 2. Biogas Conversion, and Using

\begin{tabular}{lc}
\hline \multicolumn{1}{c}{ Using } & Energy $1 \mathrm{~m}^{3}$ Biogas \\
\hline Lighting & Lamp $60-100$ watt up to 6 hours \\
Cooking & cooking 3 kinds of foods for $5-6$ person \\
Energy & Charge 1 handphone up to 2 hours \\
Electricity & $4,7 \mathrm{kWh}$ electrical energy
\end{tabular}

Source: Suriawiria (2005) and Suhendra (2008) in Hanif (nd)

\section{MATERIALS AND METHODS}

Methods of this research are mix methods between qualitative and quantitative method. The location of this research at Supit Urang landfill in Malang city.

Primary data collected with questionaire and secondary data from Hygiene and Urban Landscaping Department Malang City. Samples are used to calculate the percentage of biogas which is used as gas fuel by citizens around landfill and the biogas potential as electrical energy using slovin formula, that are:

$$
n=\frac{N}{1+N e^{2}}
$$

where:

$\mathrm{n}$ is sample measure

$\mathrm{N}$ is population measure

$\mathrm{e}$ is error

The number of population around Supit Urang landfill which are using biogas as gas fuel are 408 houses from 5 region that are region $3,4,5,7$ and 8 . With $10 \%$ error, sample measure is:

$$
n=\frac{408}{1+408(0,1)^{2}}=80,31=81
$$

Sample obtained with purposive stratified random sampling method of each region, that are:

Table 3. Sample Number in Each Region

\begin{tabular}{lcccccc}
\hline \multicolumn{1}{c}{ Region } & 3 & 4 & 5 & 7 & 8 & Total \\
\hline Population & 70 & 88 & 107 & 76 & 67 & 408 \\
Sample & 14 & 17 & 22 & 15 & 13 & 81 \\
\hline
\end{tabular}

Source: analysis result 
The analysis to know the correlation between the number of population and the amount of waste in Malang city, then the amount of organic waste and biogas potential uses SPSS version 19. Biogas potential analysis to know the percentage of biogas which are used as gas fuel, and the percentage of biogas potency as electrical energy uses Microsoft Excell.

\section{RESULT AND DISCUSSION \\ Population Number and Waste Amount}

Based on data from Statistics of Malang City, Malang City's population number 2013 is 840.800 with the average of growth rate per year is $0,81 \%$. The average of waste amount in Malang City is 410,45 ton/year.

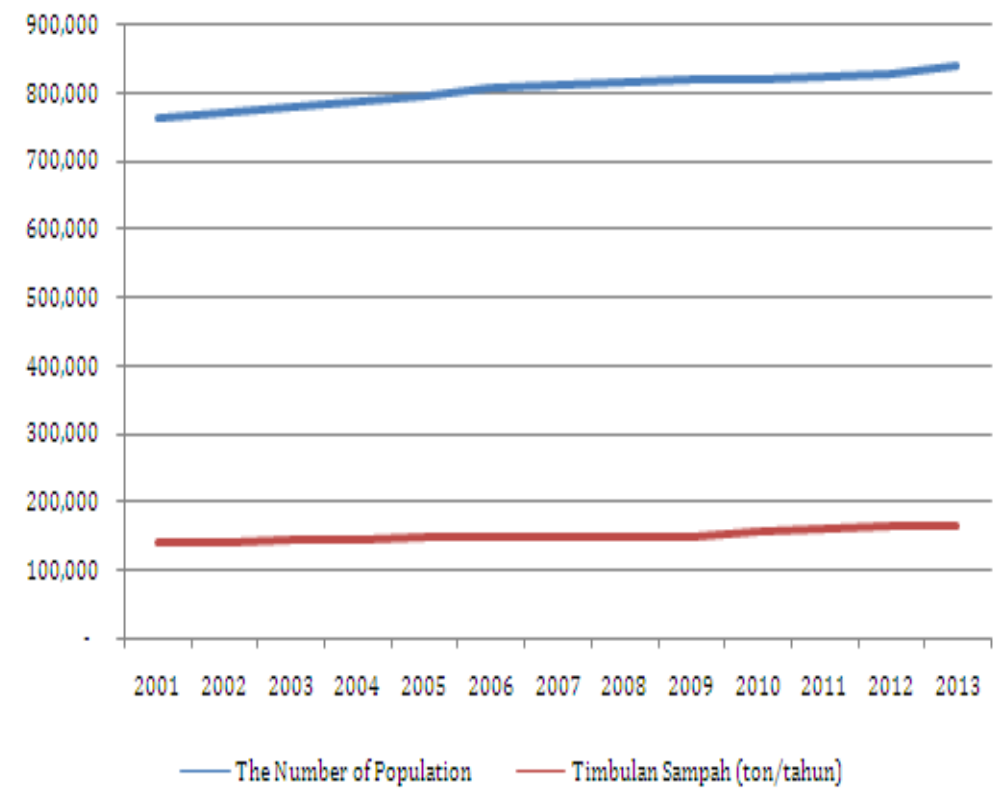

Source: Statistics of Malang City and Hygiene and Urban Landscaping Department Malang City (2014)

Fig. 1 Population number and waste amount Malang City

Correlation between population number with waste amount is 0.892 . This value is adequately high and significant with $\mathrm{p}$-value of 0 . The correlation between organic waste and biogas potential is 1 . This value is so high and significant with $p$-value of 0 as seen at Table 4.

Table 4. Correlation Analysis

\begin{tabular}{lcc}
\hline \multicolumn{1}{c}{ Variabel } & Pearson Correlation & p-value \\
\hline Population Number - Waste amount & 0.892 & 0.000 \\
Organic Waste - Biogas Potency & 1.000 & 0.000 \\
\hline
\end{tabular}

Source: analysis result

An increase in the number of population will cause an increase in the amount of waste. It happens because waste results from human life activity. Therefore, if the population number increase, waste amount also increase too. The increasing of organic waste cause greater biogas potential. It happens because biogas results from organic waste fermentation.
Eddine and Salah (2012) stated that the composition of MSW is closely related to lifestyle of the residents and economic development. In general, the composition of MSW in Malang City with eleven major categories of waste was identified: organics, paper and cardboard, plastics, glass, metals, textile, rubber, bones, hazardous waste, inert, and residues that can be seen at Fig 2. 


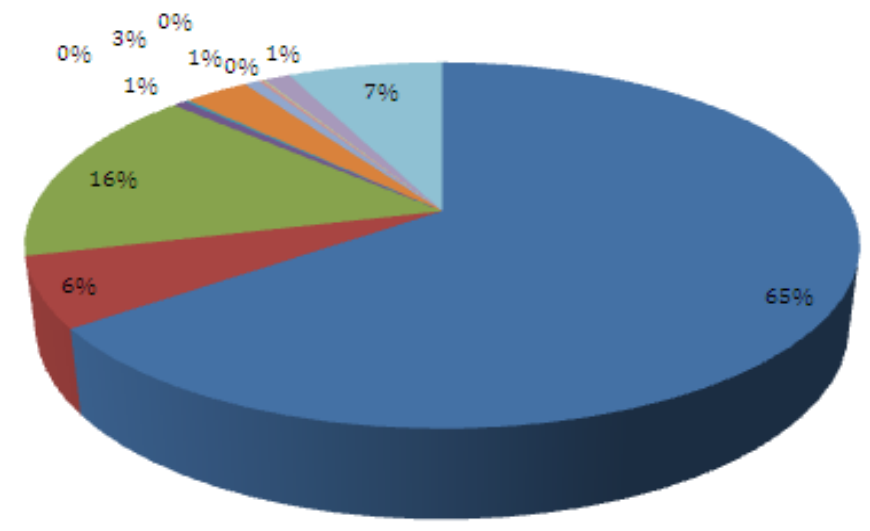

$$
\begin{aligned}
& \text { norganics = Paper \& Cardboardm Plastics Glass } \\
& \text { Metals } \quad \text { Textile Rubber } \\
& \text { Hazardous Waste Inert Inesidues }
\end{aligned}
$$

Source: Ministry of Public Worksand KfW German Development Bank (2011)

Fig. 2 Waste Composition in Malang City

\section{Waste Management}

Waste service at Malang City have reached $96,5 \%$ regions service. Meanwhile 3,5\% regions is river boundary that is difficult to reach, because that regions are so steep.

Malang City have 1 landfill and 69 dumps. Malang City also have 1 waste transition station. Waste transition station is built as one of strategy to economize waste transportation which goes to landfill. Four times ritasi of waste transportation can be economized as once ritasi only, with waste condensation mechanism from waste volume about $40-50 \mathrm{~m}^{3}$ become $9,2 \mathrm{~m}^{3}$.

Waste are taken from dumps which are scattered at every district in Malang City. Part of that waste (from 4 districts) is transported to go to waste transition station. Meanwhile the others directly go to landfill.

Several waste management process was begun from family scale, that are sorting inorganic waste, composting, and also worm conducting. Meanwhile the residue are taken in to Supit Urang landfill. Waste at Supit Urang are flattened then condensed and buried every 1 meter. Biogas's catching pipe is placed in the already buried waste.

\section{Biogas's Potential at Supit Urang Landfill}

The average of waste amount at Malang City is 410,45 tons/day with organic waste composition at Supit Urang landfill reaching $64,9 \%$ or average about $137.989,57 \mathrm{~kg} /$ day. From that amount, the average of biogas resulted is $19.146,57 \mathrm{~m}^{3} /$ day or about $574.397,05$ $\mathrm{m}^{3} /$ month.
In average, people utilizes biogas's stove up to 4,5 hours per day or 135,19 hours/month. If each $1 \mathrm{~m}^{3}$ biogas can be utilized to cook up to 3 hours therefore biogas need for one house is about $1,5 \mathrm{~m}^{3} /$ day or $45,06 \mathrm{~m}^{3} /$ month. Biogas already being utilized by 408 houses around landfill or about $612,84 \mathrm{~m}^{3} /$ day or about $18.385,19 \mathrm{~m}^{3} /$ month. The percentage of biogas's utilization as gas fuel by citizen is $3,2 \%$.

Therefore, there's still available biogas potential of about $556.011,86 \mathrm{~m}^{3} /$ month. That potential has not been utilized yet as is so big, that is about $96,8 \%$. If that potential are used as electrical energy, with assumption $1 \mathrm{~m}^{3}$ biogas has the same measure as $4.7 \mathrm{kWh}$, that biogas's potential can produce electrical energy as big as 2.613.255,75 kWh/month or about 3,63 MW. If the average of efficiency level of conversion biogas to electricity is $35 \%$, so the electric potential becomes $914.639,51 \mathrm{kWh}$ per month or as big as power station with energy 1,27 MW. 
Table 5. Biogas Potency Analysis

\begin{tabular}{cccc}
\hline Year & TS (kg/day) & VS (kg/day) & Biogas Potency/ VBS $\left(\mathrm{m}^{3} /\right.$ day $)$ \\
\hline 2001 & $41.154,72$ & $30.495,65$ & $20.615,06$ \\
2002 & $41.154,72$ & $30.495,65$ & $20.615,06$ \\
2003 & $49.148,95$ & $36.419,37$ & $24.619,50$ \\
2004 & $44.824,55$ & $33.214,99$ & $22.453,33$ \\
2005 & $36.585,53$ & $27.109,88$ & $18.326,28$ \\
2006 & $35.181,82$ & $26.069,73$ & $17.623,14$ \\
2007 & $32.761,54$ & $24.276,30$ & $16.410,78$ \\
2008 & $32.328,11$ & $23.955,13$ & $16.193,67$ \\
2009 & $31.709,49$ & $23.496,74$ & $15.883,79$ \\
2010 & $35.008,94$ & $25.941,63$ & $17.536,54$ \\
2011 & $35.192,17$ & $26.077,39$ & $17.628,32$ \\
2012 & $41.500,47$ & $30.751,85$ & $20.788,25$ \\
2013 & $40.349,43$ & $29.898,93$ & $20.211,68$ \\
Average & $38.223,11$ & $28.323,33$ & $19.146,57$ \\
\hline
\end{tabular}

Source: Analysis result

\section{CONCLUSIONS} that:

Based on this research, it can be concluded

1. Population number and waste amount has high positive correlation that is 0.863 with significant level ( $p$ value) of 0 . Meanwhile organic waste amount and biogas potential also has high positive correlation that is 1 with significant level ( $p$ value) of 0 .

2. The percentage of biogas which has already been utilized as gas fuel by citizen is just $3,2 \%$ or about $612,84 \mathrm{~m}^{3} /$ day or $18.385,19$ $\mathrm{m}^{3} /$ month.

3. The percentage of biogas that has not been utilized yet are still so big, that is $96,8 \%$. If it is converted as electrical energy the biogas potential can produce electrical energy as big as $2.613 .255,75 \mathrm{kWh} / \mathrm{month}$ or about $3,63 \mathrm{MW}$. With $35 \%$ as the efficiency level of conversion biogas to electricity, the electric potency become 914.639,51 kWh per month or about $1,27 \mathrm{MW}$.

\section{REFERENCES}

Abreu, F.V.D, Mila, R.A, Mauro, C.L.S., Diego, P.M. 2011. Technical and Economical Feasibility Analysis Of Energy Generation Though The Biogas From The Waste in Landfill. Journal Of Petroleum Technology and Alternative Fuels. 2 (6). 95-102. http://www.academicjournals.org/article/ article1380013642_Viana\%20de\%20Abreu\% 20pdf.pdf. Accessed 15 July 2014.

Czepiel, P.M., Shorter, J.H., Mosher, B., Alwlwine, E., McManus, J.B., Harris, R.C., Kolb, C.E. and Lamb, B.K. 2003. The Influence of Atmospheric Pressure On Landfill Methane Emissions. Waste

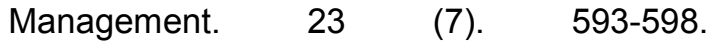
https://vpn.undip.ac.id. Accessed 17 September 2013.

Eddine, B.T and Salah, M.M. 2012. Solid Waste As Renewable Source of Energy: Current and Future Possibility in Algeria. International Journal of Energy and Environmental Engineering 2012, 3:17. http://www.journalijeee.com/content/pdf/2251 -6832-3-17.pdf. Accessed 21 July 2014.

Eurelectric. 2003. Efficiency in Electricity Generation. Brussels. Union Of The Electricity Industri.

Hanif, A. nd. Studi Pemanfaatan Biogas Sebagai Pembangkit Listrik $10 \mathrm{~kW}$ Kelompok Tani Mekarsari Desa Dander Bojonegoro Menuju Desa Mandiri Energi. http://digilib.its.ac.id /public/ITS-Undergraduate-165122208100628-Paper.pdf. Accessed 6 July 2014. 
Kementerian PU and KfW German Development Bank. 2011. Feasibility Study For Selected Measures in Malang, Jombang, Jambi And Result Of Additional Tasks: Waste Composition Survey Report. Stuttgart. Fichtner.

Kementerian Negara Riset dan Teknologi RI. 2006. Buku Putih Penelitian, Pengembangan, dan Penerapan IImu Pengetahuan dan Teknologi Energi Baru dan Terbarukan untuk Mendukung Keamanan Ketersediaan Energi Tahun 2005 - 2025. http://www.batan.go.id/ ref_utama/buku_putih_energi.pdf. Accessed 18 March 2014.

Ngumah, C., Ogbulie, J., Orji, J., dan Amadi, E. 2013. Potential Of Organic Waste For Biogas And Biofertilizer Production in Nigeria. Environmental Research, Engineering dan Management, 2013. No. 1(63), P. 60-66. http://www.erem.ktu.It/ index.php/erem/article/download/2912/2415. Accessed 21 July 2014.

Pierpaoli, P and Diotallevi, A. 2007. Generating Electrical Energy From Landfill Gas: An Italian Experience. International Energy Journal $8 . \quad 45-50$. http://www.rericjournal.ait.ac.th/index.php/ reric/article/viewFile/176/138. Accessed 15 July 2014.

Scharff, H dan Jacobs, J. 2006. Applying Guidance For Methane Emission Estimation For Landfills. Waste Management. 26(4). 417-429. http://www.afvalzorg.nl. Accessed 10 September 2013.

Sudrajat, H.R. 2006. Mengelola Sampah Kota. Jakarta. Penebar Swadaya.

Sulistyo, A. 2010. Analisis Pemanfaatan Sampah Organik Sebagai Bahan Baku Biogas di Pasar Induk Kramat Jati. Tesis. Jakarta. Fakultas Teknik Universitas Indonesia. http://lontar.ui. ac.id. Accessed 3 February 2014. 